\title{
Genetic diversity and structure in fragmented populations of the endangered species Ranunculus cabrerensis (Ranunculaceae): implications for conservation
}

\author{
Eduardo Cires $^{1 *}$, Candela Cuesta ${ }^{2,3}$ \& José Antonio Fernández Prieto ${ }^{1}$ \\ ${ }^{1}$ Área de Botánica. Universidad de Oviedo, Departamento de Biología de Organismos y Sistemas, Catedrático Rodrigo Uría \\ s/n,33071 Oviedo, Spain; e-mail: cireseduardo@gmail.com \\ ${ }^{2}$ Área de Fisiología Vegetal. Universidad de Oviedo, Departamento de Biología de Organismos y Sistemas, Catedrático \\ Rodrigo Uría s/n, 33071 Oviedo, Spain \\ ${ }^{3}$ Department of Plant Systems Biology, VIB, Technologiepark 927, 9052 Ghent, Belgium
}

\begin{abstract}
Ranunculus cabrerensis is an endemic and endangered species of the Northwestern Iberian Peninsula. The molecular markers AFLP and ISSR were used to investigate the genetic diversity and population structure of four populations across its known distribution. Fifteen selective primer combinations of AFLP and seventeen ISSR primer combinations produced a total of 2830 and 103 unambiguously repeatable fragments respectively, of which 97.57 and $81.38 \%$ were polymorphic for both markers. The genetic diversity of $R$. cabrerensis at species level was high $\left(H_{\mathrm{E}}=0.294\right.$ by ISSR and $H_{\mathrm{E}}$ $=0.191$ by AFLP) and differentiation between sampled locations was also relatively high $\left(G_{\mathrm{ST}}=0.316\right.$ and 0.158 by ISSR and AFLP analysis respectively) compared to other studies of endangered and rare species using the same techniques. The analysis of molecular variance (AMOVA) indicated that the main genetic variation was within sampled locations $(73 \%$ by AFLP; $52 \%$ by ISSR), even though the variation among locations was also significant. Principal Coordinates, NeighborNet and Bayesian analyses revealed a weak but significant relationship between the genetic structures of different populations in R. cabrerensis, with gene flow acting as a homogenizing force that prevents stronger differentiation of populations. Finally, suggestions for conservation strategies to preserve the genetic resources of this species are outlined.
\end{abstract}

Key words: AFLP; endemism; endangered species; genetic diversity; ISSR; plant conservation; population differentiation; Ranunculaceae, structure; $\Delta K$

\section{Introduction}

In the last decade, an increasing number of studies have demonstrated the value of genetic data in addressing issues of plant conservation biology, especially in rare and narrowly endemic species (e.g. Gaudeul et al. 2000; Bellusci et al. 2008; González-Pérez et al. 2009). Genetic variation within a taxon is thought to be crucial for the long-term survival and continued evolution of populations or species (Frankham et al. 2004). Experimental and field investigations have demonstrated that fragmented populations may lose allelic richness or genetic diversity, and have increased population differentiation due to genetic drift and inbreeding depression (e.g. Buza et al. 2000; Tomimatsu \& Ohara 2003). Thus, an accurate estimate of the level and distribution of genetic diversity of threatened and endangered species is an important element in designing conservation programmes (Smith \& Wayne 1996; Höglund 2009).

In the present study, an attempt to examine the impact of habitat fragmentation on the genetic diversity and population structure of Ranunculus cabreren- sis Rothm., an endangered plant with a narrow distribution in the Northwestern Iberian Peninsula, was conducted. Such population genetic information is a prerequisite to understanding the species' chance of survival in the short-term, so that an effective conservation strategy for long-term survival can be formulated and implemented. In the past, $R$. cabrerensis was treated as a subspecies of the $R$. parnassiifolius s.l. polyploid complex. However, as a result of recent studies, we have put forward numerous arguments to support the separation of these taxa, and consequently to treat them as independent species (Cires 2011; Cires \& Fernández Prieto 2012). In addition to this, within $R$. cabrerensis it is possible to differentiate two subspecies: $R$. cabrerensis subsp. cabrerensis and R. cabrerensis subsp. muniellensis (Bueno, Fern.Casado \& Fern.Prieto) Fern.Prieto \& Cires (for more details on the subspecies differentiation at morphological and molecular level see Bueno et al. (1992); Cires (2011); Cires \& Fernández Prieto (2012)). The first grows in small, localised populations on rock-fields and coarse rocky screes (rock-slides) at altitudes of 1750 to $2450 \mathrm{~m}$,

\footnotetext{
* Corresponding author
} 


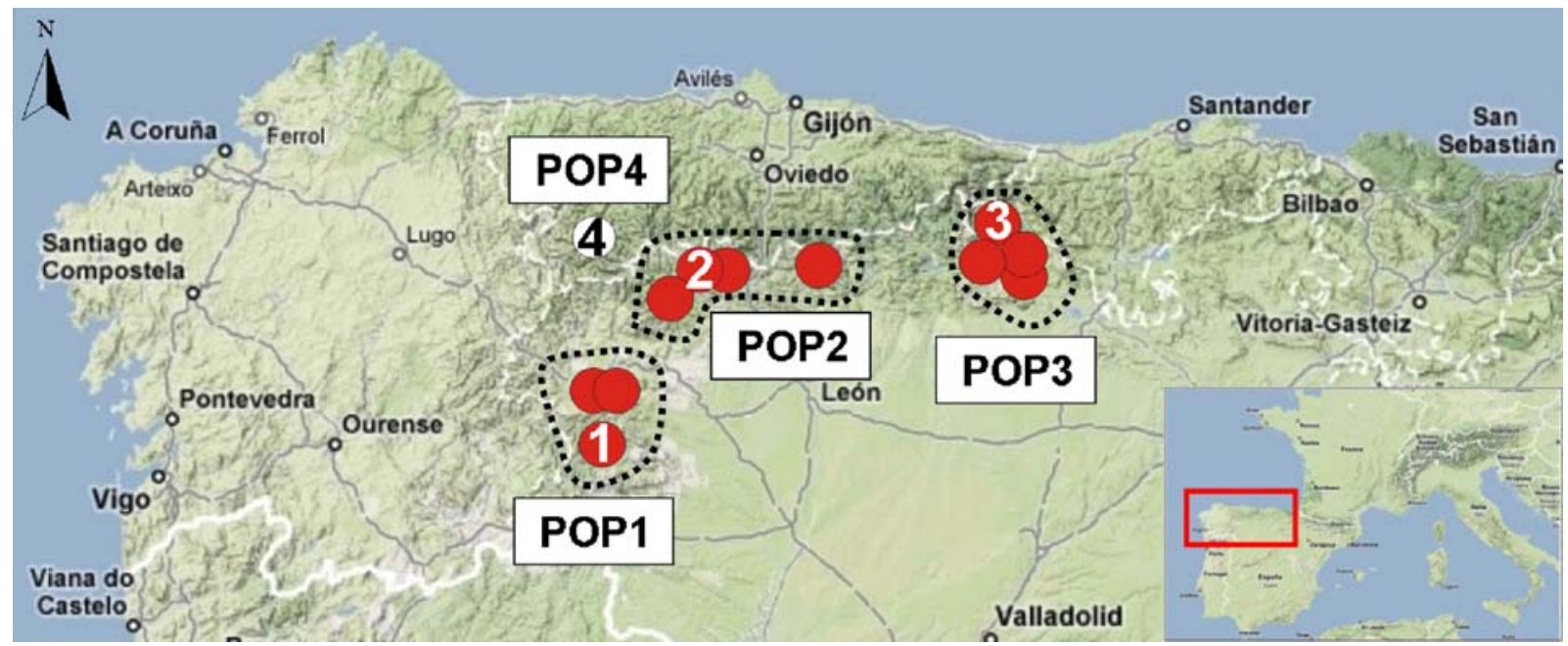

Fig. 1. Locations of four populations of Ranunculus cabrerensis s.l. of the Northwestern Iberian Peninsula. POP1: Lago de la Baña; POP2: Abelgas de Luna; POP3: Portillo de las Yeguas; POP4: Muniellos Biosphere Reserve. Open circles (o): distribution of R. cabrerensis subsp. muniellensis (a single population is known). Filled circles (•): global distribution of $R$. cabrerensis subsp. cabrerensis.

in the region of Castile and Leon (Northwest Iberian Peninsula). Currently, Spanish national legislation lists $R$. parnassiifolius s.l. (i.e. not specifying any particular subspecies) without any specific category (Real Decreto 139/2011); nevertheless, previous legislation catalogued $R$. parnassiifolius subsp. cabrerensis $(=R$. cabrerensis subsp. cabrerensis) under the category of "special interest" (Orden MAM/2734/2002). Additionally, it should be noted that this plant is considered "rare" by several regional catalogues (Llamas et al. 2007) and has not been included in the National Red List of threatened plants for Spain (see VV AA 2000; Bañares et al. 2004; Moreno 2008). The second subspecies occurs naturally in siliceous screes in the Muniellos Biosphere Reserve (Western Cantabrian Mountains, Asturias, Iberian Peninsula), and at the moment, only a single population is known. In regard to its protected status, this subspecies does not appear in the regional catalogue of threatened species for Asturias. Indeed, in the Red List of Spanish Vascular Flora (VV AA 2000) it appears under the category of "data deficient", while in Bañares et al. (2004) and Moreno (2008) it is listed as "vulnerable". Fernández Prieto et al. (2007) proposed the inclusion of this plant in the catalogue of threatened vascular plants of Asturias under the category of "vulnerable".

Despite its rarity, its patchy distribution and the endangered status of this endemic taxon, there is no population genetic study and conservation management plan for the species to date. As an initial step in developing such a plan, we have assessed the genetic diversity and population structure of four natural populations of $R$. cabrerensis s.l. using Inter Simple Sequence Repeat (ISSR) (Zietkiewicz et al. 1994) and Amplified Fragment Length Polymorphisms (AFLP) (Vos et al. 1995). ISSR and AFLP have advantages over other DNA polymorphism analysis methods, as they do not require prior sequence knowledge, cloning procedures or characterized probes. It is generally accepted that they have a comparatively high reproducibility (Jones et al. 1997), and as a result, AFLP and ISSR have both been used to investigate within-species genetic variation (e.g. Ci et al. 2008; Cuesta et al. 2010). Moreover, both techniques have been successfully used in plant population genetic studies, especially for endangered species (e.g. Li \& Jin 2007; Gong et al. 2010).

Here, we report a genetic variability analysis on Ranunculus cabrerensis, performed from a conservation perspective. The following questions were examined: (1) what is the level of genetic diversity in populations of $R$. cabrerensis s.l.? (2) how is genetic diversity distributed within and between populations? And finally, (3) how are the populations related, and is there a geographical correlation? In addition to assess the levels of genetic variability in the endangered species $R$. cabrerensis, the results of this study are used to propose conservation and management strategies.

\section{Material and methods}

\section{Sample collection and DNA extraction}

Four natural populations of $R$. cabrerensis s.l., covering the whole range of the subspecies (Fig. 1), were collected between 2007 and 2008, and mapped using GPS (Garmin) (Table 1). From each site, plants were randomly sampled and leaves were taken from individuals that were at least $3 \mathrm{~m}$ apart, to avoid duplicate sampling. Leaves were stored on moistened paper, enclosed in a plastic bag and kept at low temperatures $\left(4^{\circ} \mathrm{C}\right)$ before and during transportation, and on arrival at the laboratory the plant tissue was frozen at $-80^{\circ} \mathrm{C}$ until analysis. In addition, voucher specimens were collected, dried by pressing in absorbent paper, stored at room temperature, and kept in the Herbarium of the University of Oviedo (FCO) (Table 1).

DNA extraction was carried out using the CTAB method described by Doyle \& Doyle (1987) with minor modifications. DNA concentration was measured by a BeckmanCoulter DU800 ${ }^{\circledR}$ spectrophotometer (Fullerton, CA, USA). 
Table 1. Code, location, population and sample size of the four examined populations of Ranunculus cabrerensis s.l.

\begin{tabular}{|c|c|c|c|c|c|}
\hline Code & $\begin{array}{l}\text { Subsp. } \\
\text { Syst. }{ }^{\dagger}\end{array}$ & Population & Coordinates & $\begin{array}{l}\text { Sample size } \\
\text { AFLP/ISSR }\end{array}$ & $\begin{array}{c}\text { Voucher } \\
\text { specimens }\end{array}$ \\
\hline POP1 & $\mathrm{RCC}$ & $\begin{array}{l}\text { *Lago de la Baña, Sierra Cabrera (Encinedo, León, Spain); } \\
2000 \mathrm{~m} ; B J A, E C \text { \& } L G ; 2007 / 06 / 14\end{array}$ & $\begin{array}{l}42^{\circ} 14^{\prime} 33.8^{\prime \prime} \mathrm{N} \\
6^{\circ} 44^{\prime} 40.0^{\prime \prime} \mathrm{W}\end{array}$ & $8 / 10$ & FCO: 31369 \\
\hline POP2 & $\mathrm{RCC}$ & $\begin{array}{l}\text { Abelgas de Luna, north of Peña Piquera (Sena de Luna, } \\
\text { León, Spain); } 1956 \mathrm{~m} ; C C \mathscr{E} E C ; 2008 / 06 / 29\end{array}$ & $\begin{array}{l}42^{\circ} 53^{\prime} 32.7^{\prime \prime} \mathrm{N} \\
6^{\circ} 4^{\prime} 59.0^{\prime \prime} \mathrm{W}\end{array}$ & $8 / 10$ & FCO: 31368 \\
\hline POP3 & $\mathrm{RCC}$ & $\begin{array}{l}\text { Portillo de las Yeguas, San Glorio (Boca de Huérgano, León, } \\
\text { Spain); } 2094 \mathrm{~m} ; A B \mathscr{G} E C ; 2007 / 06 / 19\end{array}$ & $\begin{array}{l}43^{\circ} 3^{\prime} 17.6^{\prime \prime} \mathrm{N} \\
4^{\circ} 44^{\prime} 20.4^{\prime \prime} \mathrm{W}\end{array}$ & $8 / 10$ & FCO: 31371 \\
\hline POP4 & $\mathrm{RCM}$ & $\begin{array}{l}\text { *Muniellos Biosphere Reserve (Cangas del Narcea, Asturias, } \\
\text { Spain); } 1464 \mathrm{~m} ; E C ; 2007 / 07 / 18\end{array}$ & $\begin{array}{l}43^{\circ} 1^{\prime} 28.6^{\prime \prime} \mathrm{N} \\
6^{\circ} 44^{\prime} 25.9^{\prime \prime} \mathrm{W}\end{array}$ & $8 / 10$ & FCO: 31370 \\
\hline
\end{tabular}

* Locus classicus

$\dagger$ Subspecific systematization of samples according to previous studies (RCC: Ranunculus cabrerensis subsp. cabrerensis; RCM: R. cabrerensis subsp. muniellensis) [see Cires (2011); Cires \& Fernández Prieto (2012) for more details].

Collector abbreviations: $\mathrm{AB}=\mathrm{A}$. Bueno; BJA = B. Jiménez-Alfaro; CC = C. Cuesta; EC = E. Cires; LG = L. González

Table 2. Primers, melting temperatures $\left(T_{\mathrm{m}}\right)$, annealing temperatures $\left(T_{\mathrm{a}}\right)$, range of molecular weight of bands per primer expressed in base pairs (bp), and number of repeatable bands scored for each ISSR used to amplify $R$. cabrerensis s.l. NB: number of bands; NPB: number of polymorphic bands; PPB: the average percentage of polymorphic bands.

\begin{tabular}{|c|c|c|c|c|c|c|c|}
\hline Primers & Sequence $\left(5^{\prime}-3^{\prime}\right)^{a}$ & $T_{\mathrm{m}}\left({ }^{\circ} \mathrm{C}\right)$ & $T_{\mathrm{a}}\left({ }^{\circ} \mathrm{C}\right)$ & Size range $(b p)$ & NB & NPB & PPB (\%) \\
\hline UBC-807 & $(\mathrm{AG})_{8} \mathrm{~T}$ & 50.4 & 49 & $700-1450$ & 5 & 4 & 80.00 \\
\hline UBC-811 & $(\mathrm{GA})_{8} \mathrm{C}$ & 52.8 & 49 & $600-1500$ & 9 & 8 & 88.89 \\
\hline UBC-812 & $(\mathrm{GA})_{8} \mathrm{~A}$ & 50.4 & 49 & $650-1200$ & 8 & 8 & 100.00 \\
\hline UBC-813 & $(\mathrm{CT})_{8} \mathrm{~T}$ & 50.4 & 49 & $700-1800$ & 7 & 6 & 85.71 \\
\hline UBC-818 & $(\mathrm{CA})_{8} \mathrm{G}$ & 52.8 & 49 & $700-1500$ & 8 & 6 & 75.00 \\
\hline UBC-825 & $(\mathrm{AC})_{8} \mathrm{~T}$ & 50.4 & 49 & $550-1200$ & 5 & 3 & 60.00 \\
\hline UBC- 828 & $(\mathrm{TG})_{8} \mathrm{~A}$ & 50.4 & 49 & $650-1500$ & 7 & 5 & 71.43 \\
\hline UBC-834 & $(\mathrm{AG})_{8} \mathrm{YC}$ & 52.6 & 52 & $275-1500$ & 8 & 7 & 87.50 \\
\hline UBC-842 & $(\mathrm{GA})_{8} \mathrm{YG}$ & 54.8 & 52 & $350-1000$ & 4 & 4 & 100.00 \\
\hline UBC-844 & $(\mathrm{CT})_{8} \mathrm{RC}$ & 54.8 & 52 & $400-1400$ & 6 & 5 & 83.33 \\
\hline UBC-855 & $(\mathrm{AC})_{8} \mathrm{YT}$ & 52.6 & 55 & $750-1550$ & 5 & 4 & 80.00 \\
\hline UBC-857 & $(\mathrm{AC})_{8} \mathrm{YG}$ & 54.8 & 55 & $300-1800$ & 10 & 10 & 100.00 \\
\hline UBC-864 & $(\mathrm{ATG})_{5}$ & 46.9 & 49 & $950-1800$ & 5 & 4 & 80.00 \\
\hline UBC-886 & $\mathrm{VDV}(\mathrm{TC})_{7}$ & 51.9 & 52 & $550-850$ & 4 & 3 & 75.00 \\
\hline LL1 & $(\mathrm{CAA})_{5}$ & 39.6 & 49 & $700-1800$ & 6 & 4 & 66.67 \\
\hline LL2 & $(\mathrm{CAG})_{5}$ & 53.3 & 62 & $750-850$ & 2 & 2 & 100.00 \\
\hline LL4 & $(\mathrm{GACA})_{4}$ & 49.2 & 52 & $1000-1500$ & 4 & 2 & 50.00 \\
\hline Total & & & & & 103 & 85 & \\
\hline
\end{tabular}

Unamplified fragments or unclear amplifications: UBC-808 (AG) ${ }_{8}$ C; UBC-820 (GT) ${ }_{8}$ C; UBC-840 (GA) 8 YT; LL3 (GATA) 4

${ }^{a} \mathrm{D}=\mathrm{A}$ or $\mathrm{G}$ or $\mathrm{T} ; \mathrm{R}=\mathrm{A}$ or $\mathrm{G} ; \mathrm{Y}=\mathrm{C}$ or $\mathrm{T} ; \mathrm{V}=\mathrm{A}$ or $\mathrm{C}$ or $\mathrm{G}$

\section{ISSR amplification}

Twenty-one ISSR primers (MWG-Biotech AG, Ebersberg, Germany) were used for the analysis. A preliminary screening was carried out using gradient annealing temperatures $\left(T_{\mathrm{a}}\right)$ in order to select primers that could give reliable patterns of amplification and also to choose a suitable annealing temperature (Table 2$)$. The PCR reaction mixture $(25 \mu \mathrm{L})$ consisted of $25 \mathrm{ng}$ of DNA, $2.5 \mu \mathrm{L}$ of $10 \times$ PCR buffer, $2 \mathrm{mM}$ $\mathrm{MgCl}_{2}, 0.2 \mu \mathrm{M}$ of primer, $0.1 \mathrm{mM} \mathrm{dNTPs}$, and $1 \mathrm{U}$ of Taq DNA polymerase (Biotools). PCR amplifications were performed using a gradient thermal cycler $\left(\mathrm{MyCycler}^{\mathrm{TM}}\right.$, BioRad) with initial denaturation at $94^{\circ} \mathrm{C}$ for 1 min followed by 40 cycles of $1 \mathrm{~min}$ at $94^{\circ} \mathrm{C}, 1 \mathrm{~min}$ at the annealing temperature $\left(T_{\mathrm{a}}\right), 2$ min elongation at $72^{\circ} \mathrm{C}$; and a final extension at $72^{\circ} \mathrm{C}$ for $10 \mathrm{~min}$. Amplification products were resolved by electrophoresis on a $2 \%$ agarose gel stained with ethidium bromide, and then photographed on a UV transilluminator (GelLogic 100, Kodak). Molecular size of the fragments was estimated using a 100-bp DNA ladder (Biolabs ${ }^{\circledR}$, New England, USA). In order to ensure the reliability of the results obtained, reactions were performed at least twice, including internal controls (replicates of the same sample in each combination, and different DNA extractions of the same individual). Only consistently reproduced, distinguishable bands were considered.

\section{AFLP amplification}

The AFLP-based PCR was carried out as has been previously described (Cires 2011; Cires et al. 2011). The genomic DNA was digested with EcoRI and MseI restriction enzymes (New England Biolabs Inc.). In the following step, double-strand adapters were ligated to EcoRI and MseI specific ends by T4 DNA Ligase (Roche Diagnostics). Products of digestion/ligation were checked by electrophoresis in $1.5 \%$ agarose. The pre-selective amplification was performed using primers with single selective nucleotides (EcoRI+A and $M s e \mathrm{I}+\mathrm{C}$ ), checked by electrophoresis in $1.5 \%$ agarose gels and subsequently diluted $(1: 10)$ in sterile de-ionised $\mathrm{H}_{2} \mathrm{O}$. Then selective amplifications were performed using EcoRI and $M s e$ I primers with three selective nucleotides (Table 3). The EcoRI-selective primers were 5'-fluorescent 
Table 3. Pairs of primers used for AFLP amplification of $R$. cabrerensis s.l. and summary of amplified bands. NB: number of bands; NPB: number of polymorphic bands; PPB: the average percentage of polymorphic bands.

\begin{tabular}{lccc}
\hline Primer pairs & NB & NPB & PPB (\%) \\
\hline EcoRI-AAC/MseI-CAT & 267 & 264 & 98.88 \\
EcoRI-AAC/MseI-CTT & 154 & 142 & 92.21 \\
EcoRI-AAC/MseI-CCAC & 111 & 103 & 92.79 \\
EcoRI-AAC/MseI-CCAG & 145 & 144 & 99.31 \\
EcoRI-AAC/MseI-CCTA & 143 & 142 & 99.30 \\
EcoRI-ACG/MseI-CAT & 297 & 297 & 100.00 \\
EcoRI-ACG/MseI-CTT & 192 & 189 & 98.44 \\
EcoRI-ACG/MseI-CCAC & 166 & 165 & 99.40 \\
EcoRI-ACG/MseI-CCAG & 101 & 97 & 96.04 \\
EcoRI-ACG/MseI-CCTA & 169 & 163 & 96.45 \\
EcoRI-ACT/MseI-CAT & 320 & 317 & 99.06 \\
EcoRI-ACT/MseI-CTT & 241 & 236 & 97.92 \\
EcoRI-ACT/MseI-CCAC & 184 & 180 & 97.83 \\
EcoRI-ACT/MseI-CCAG & 172 & 169 & 98.25 \\
EcoRI-ACT/MseI-CCTA & 168 & 164 & 97.62 \\
\hline Total & 2830 & 2772 & \\
\hline
\end{tabular}

labelled. Selective amplification products were submitted to the Sequencing Services from the University of Oviedo for fragment analysis: samples were run on an automated DNA sequencer (ABI PRISM ${ }^{\circledR}$ 3100, Applied Biosystems) with an internal size standard GeneScan $500\left(\mathrm{ROX}^{\mathrm{TM}}\right.$, Applied Biosystems). Five randomly chosen samples were analyzed in duplicate and used as positive controls to verify the reproducibility of AFLP analyses. Raw AFLP data were collected and sized using the Genemapper 4.0 software (Applied Biosystems).

\section{Genetic diversity analysis}

Since ISSR and AFLP are dominant markers, and given that the species is diploid, we assumed that each band represented the phenotype at a single biallelic locus. Amplified fragments were scored for presence (1) or absence (0) of comigrating bands. The resulting binary data matrices of AFLP and ISSR phenotypes were analyzed using GenAlEx 6.4 (Peakall \& Smouse 2006) to estimate the following genetic diversity parameters, assuming Hardy-Weinberg equilibrium: observed number of bands (NB), number of polymorphic bands (NPB), percentage of polymorphic bands (PPB), mean observed number of alleles $\left(A_{\mathrm{O}}\right)$, mean effective number of alleles $\left(A_{\mathrm{E}}\right)$, number of private alleles (i.e. unique for respective population but not common for all of its samples, $A_{\mathrm{P}}$ ), number of discriminating alleles (i.e. present in all analyzed samples of a respective population and absent elsewhere, $\left.A_{\mathrm{D}}\right)$, Nei's gene diversity $\left(H_{\mathrm{E}}\right)$, and finally Shannon diversity index $(I)$. The population genetic structure $G_{\mathrm{ST}}$ was computed using AFLP-SURV 1.0 (Vekemans 2002) which estimates allele frequencies at each locus in each population for dominant markers, assuming two alleles per locus. We used Bayesian method with non-uniform prior distribution of allele frequencies (Zhivotovsky 1999). Gene flow $(\mathrm{Nm})$ among populations was estimated indirectly from the equation $N m=\left(1-G_{\mathrm{ST}}\right) / 4 G_{\mathrm{ST}}$ (Nei 1977; Slatkin \& Barton 1989).

An analysis of molecular variance (AMOVA) was performed to further explore the genetic structure of the studied populations. AMOVA works with the squared Euclidian genetic distances between all individuals and allows the partitioning of variance among and within populations. In addition, a Mantel test was performed to test the correlation between geographical distance between pairs of populations and Nei's genetic distance (Nei 1972) (computing 9999 permutations). The AMOVA and Mantel test were performed using the program GenAlEx 6.4 (Peakall \& Smouse 2006). In addition to this, the relationship between genetic distance, expressed as $F_{\mathrm{ST}}$ and geographic distance was further examined using the software BARRIER 2.2 (Manni et al. 2004) which implements Monmonier's maximum difference algorithm to test the presence of genetic barriers among groups.

Principal Coordinates Analysis (PCoA) was performed on the Jaccard similarity matrix to visualize the genetic relationships among all individuals analyzed with ISSR and AFLP markers using Past 1.89 (Hammer et al. 2001). To further substantiate the assessment of population genetic structure, a model-based Bayesian inference clustering was run using Structure 2.3 (Pritchard et al. 2000; Falush et al. 2007). For the Structure analyses, we used an admixture model and uncorrelated allele frequencies between clusters. Nine independent runs were carried out for each value of $K$ ranging from 1 to 10 , with a burn-in period of $2 \times 10^{5}$ and $1 \times 10^{5}$ Markov Chain Monte Carlo replicates after burn-in. To infer the number of genetic groups in our data set, we used the $\Delta K$ method of Evanno et al. (2005), which consists in finding the breakpoint in the slope of the distribution of $\ln \operatorname{Pr}(X / K)$ for the different $K$ values tested, where $\ln \operatorname{Pr}(X / K)$ is an estimate of the posterior probability of the data for a given $K$. Evanno et al. (2005) showed that this $\Delta K$ method actually detects the uppermost level of population structure when several hierarchical levels exist.

Finally, NeighborNet analysis was performed in SplitsTree 4.11 (Huson \& Bryant 2006) to construct an unrooted network (uncorrected P, NeighborNet distance) of relationships among individuals based on the presence-absence matrix for all populations. Bootstrap analysis was performed on ISSR and AFLP dataset using 5,000 replicates.

\section{Results}

\section{ISSR and AFLP polymorphism}

Seventeen ISSR primers that produced clear and repeatable fragments were chosen for subsequent analysis (Table 2). These primers consistently amplified a total of 103 scored bands that ranged in size from 275 to $1800 \mathrm{bp}$. The average number of bands produced by each primer was 6.06 . Furthermore, 85 bands were polymorphic at the species level $(81.38 \%)$.

The fifteen selective primer combinations used for AFLP analysis generated 2830 fragments ranging from 50 to $500 \mathrm{bp}$, with an average of 188.67 bands per primer combination (Table 3). Polymorphic products in these combinations ranged from 97 to 317 , with an average of 184.80 per combination $(97.57 \%)$. The mean error statistic for duplicate samples was $1.6 \%$ and therefore not likely to significantly affect the results. Hence, reliability of the AFLP technique at every step was confirmed.

\section{Genetic diversity within populations}

A summary of the genetic within-population diversity 
Table 4. Genetic diversity in R. cabrerensis s.l. determined by ISSR and AFLP markers at population, subspecies and species level. Population codes are as shown in Table 1.

\begin{tabular}{|c|c|c|c|c|c|c|c|c|c|}
\hline Level & PPB & $A_{\mathrm{O}} \pm \mathrm{SE}$ & $A_{\mathrm{E}} \pm \mathrm{SE}$ & $H_{\mathrm{E}} \pm \mathrm{SE}$ & $I \pm \mathrm{SE}$ & $A_{\mathrm{P}}$ & $A_{\mathrm{D}}$ & $G_{\mathrm{ST}}$ & $\mathrm{Nm}$ \\
\hline \multicolumn{10}{|c|}{ ISSR } \\
\hline \multicolumn{10}{|l|}{ Populations } \\
\hline POP1 & 36.89 & $1.223 \pm 0.067$ & $1.260 \pm 0.037$ & $0.146 \pm 0.020$ & $0.213 \pm 0.029$ & 3 & 0 & & \\
\hline POP2 & 31.07 & $1.136 \pm 0.068$ & $1.237 \pm 0.038$ & $0.130 \pm 0.020$ & $0.188 \pm 0.028$ & 2 & 1 & & \\
\hline POP3 & 32.04 & $1.058 \pm 0.075$ & $1.229 \pm 0.036$ & $0.130 \pm 0.019$ & $0.189 \pm 0.028$ & 2 & 1 & & \\
\hline POP4 & 54.37 & $1.427 \pm 0.068$ & $1.404 \pm 0.041$ & $0.223 \pm 0.022$ & $0.323 \pm 0.031$ & 3 & 0 & & \\
\hline Average & 38.59 & 1.211 & 1.283 & $0 . \overline{157}$ & $0 . \overline{228}$ & 2.5 & 0.5 & & \\
\hline \multicolumn{10}{|l|}{ Subspecies } \\
\hline $\mathrm{RCC}$ & 69.90 & $1.670 \pm 0.052$ & $1.462 \pm 0.039$ & $0.262 \pm 0.020$ & $0.386 \pm 0.028$ & 12 & 0 & & \\
\hline $\mathrm{RCM}$ & 54.37 & $1.427 \pm 0.068$ & $1.404 \pm 0.041$ & $0.223 \pm 0.022$ & $0.323 \pm 0.031$ & 3 & 0 & & \\
\hline Average & 62.13 & 1.549 & 1.433 & 0.243 & 0.355 & 7.5 & 0 & & \\
\hline Species & 82.52 & $1.825 \pm 0.038$ & $1.508 \pm 0.036$ & $0.294 \pm 0.018$ & $0.439 \pm 0.024$ & & & 0.316 & 0.541 \\
\hline \multicolumn{10}{|c|}{ AFLP } \\
\hline \multicolumn{10}{|l|}{ Populations } \\
\hline POP1 & 52.16 & $1.105 \pm 0.018$ & $1.242 \pm 0.006$ & $0.149 \pm 0.003$ & $0.232 \pm 0.005$ & 213 & 0 & & \\
\hline POP2 & 36.64 & $0.873 \pm 0.017$ & $1.182 \pm 0.006$ & $0.110 \pm 0.003$ & $0.169 \pm 0.005$ & 125 & 0 & & \\
\hline POP3 & 62.61 & $1.300 \pm 0.017$ & $1.284 \pm 0.006$ & $0.175 \pm 0.003$ & $0.274 \pm 0.005$ & 515 & 0 & & \\
\hline POP4 & 44.73 & $0.997 \pm 0.018$ & $1.224 \pm 0.006$ & $0.136 \pm 0.003$ & $0.209 \pm 0.005$ & 213 & 7 & & \\
\hline Average & 49.03 & 1.069 & 1.233 & 0.143 & 0.221 & 266.5 & 1.7 & & \\
\hline \multicolumn{10}{|l|}{ Subspecies } \\
\hline $\mathrm{RCC}$ & 89.68 & $1.822 \pm 0.010$ & $1.289 \pm 0.006$ & $0.185 \pm 0.003$ & $0.301 \pm 0.004$ & 1274 & 3 & & \\
\hline $\mathrm{RCM}$ & 44.73 & $0.997 \pm 0.018$ & $1.224 \pm 0.006$ & $0.136 \pm 0.003$ & $0.209 \pm 0.005$ & 213 & 7 & & \\
\hline Average & 67.20 & 1.410 & 1.257 & 0.161 & 0.255 & 743.5 & 5 & & \\
\hline Species & 97.95 & $1.980 \pm 0.003$ & $1.298 \pm 0.006$ & $0.191 \pm 0.003$ & $0.312 \pm 0.004$ & & & 0.158 & 1.332 \\
\hline
\end{tabular}

RCC: Ranunculus cabrerensis subsp. cabrerensis; RCM: R. cabrerensis subsp. muniellensis

$\mathrm{PPB}$, percentage of polymorphic bands; $A_{\mathrm{O}}$, observed mean number of alleles per locus; $A_{\mathrm{E}}$, effective mean of alleles per locus; $H_{\mathrm{E}}$, expected heterozygosity; $I$, Shannon diversity index; $A_{\mathrm{P}}$, number of private alleles; $A_{\mathrm{D}}$, number of discriminating alleles; $G_{\mathrm{ST}}$, coefficient of genetic differentiation among populations; $\mathrm{Nm}$, gene flow.

for each of the four populations of $R$. cabrerensis s.l., based on ISSR and AFLP markers, is given in Table 4. According to ISSR analysis, the percentage of polymorphic loci at the population level was low, ranging from $31.07 \%$ (POP2) to $54.37 \%$ (POP4), with an average of $38.59 \%$. The number of alleles per locus ranged from 1.058 to 1.427 , with an average value of 1.211 , while the effective number of alleles per locus ranged from 1.229 to 1.404 , with an average value of 1.283 . The Nei's gene diversity ranged from 0.130 to 0.223 with an average value of 0.157 . The Shannon's information index ranged from 0.188 to 0.323 with an average value of 0.228 , and finally the genetic diversity at population level was relatively low, whereas the total genetic diversity at the species level was high $\left(\mathrm{PPB}=82.52 \% ; H_{\mathrm{E}}\right.$ $=0.294 ; I=0.439)$.

In the case of AFLP analysis, the percentage of polymorphic loci at the population level was moderately low and widely variable among populations, with a minimum value of $36.64 \%$ (POP2), a maximum of $62.61 \%$ (POP3), and an average of $49.03 \%$. The number of alleles per locus ranged from 0.873 to 1.300 with an average value of 1.069 ; while the effective number of alleles per locus ranged from 1.224 to 1.284 , with an average value of 1.233 . The Nei's gene diversity ranged from 0.110 to 0.175 and the Shannon's index ranged from 0.169 to 0.274 , with mean values of 0.143 and
0.221 respectively. As was the case with ISSR, the genetic diversity at population level was relatively low, while the total genetic diversity at the species level was high $\left(\mathrm{PPB}=97.95 \% ; H_{\mathrm{E}}=0.191 ; I=0.312\right)$.

Both in the ISSR and AFLP analysis, the genetic diversity among subspecies was much higher than within populations. Furthermore, a high number of private fragments were found between the subspecies. In addition to this, $R$. cabrerensis subsp. cabrerensis and R. cabrerensis subsp. muniellensis were differentiated by three and seven discriminating fragments respectively.

\section{Genetic diversity among populations}

The AMOVA analysis from the distance matrices for the individuals studied permitted partitioning of the overall variation into two levels (Table 5). The proportion of variation attributable to within-population differences was relatively high $(52 \%$ by ISSR; $73 \%$ by AFLP). The genetic differentiation among populations detected by ISSR was $48 \%(P<0.001)$, while only a small amount of variation $(27 \%)$ was detected among populations with AFLP $(P<0.001)$. The coefficient of genetic differentiation between populations $\left(G_{\mathrm{ST}}\right.$, the proportion of the interpopulation gene diversity) was 0.316 with ISSR, and 0.158 with AFLP (Table 4). All the estimates of genetic differentiation indicated a rel- 
Table 5. Analysis of molecular variance among and within six populations of R. cabrerensis s.l. based on ISSR and AFLP data.

\begin{tabular}{|c|c|c|c|c|c|c|}
\hline Source of variation & $\mathrm{df}$ & SS & MS & $\mathrm{VC}$ & $\%$ & $P$ value* \\
\hline \multicolumn{7}{|c|}{ ISSR } \\
\hline Among populations & 3 & 233.000 & 77.667 & 7.009 & 48 & $<0.001$ \\
\hline Within populations & 36 & 272.800 & 7.578 & 7.578 & 52 & $<0.001$ \\
\hline Total & 39 & 505.800 & & 14.587 & 100 & \\
\hline \multicolumn{7}{|c|}{ AFLP } \\
\hline Among populations & 3 & 3142.094 & 1047.365 & 97.237 & 27 & $<0.001$ \\
\hline Within populations & 28 & 7545.125 & 269.469 & 269.469 & 73 & $<0.001$ \\
\hline Total & 31 & 10687.219 & & 366.706 & 100 & \\
\hline
\end{tabular}

df, degree of freedom; SS, sum of squares; MS, mean of squares; VC, variance component; \%, total variation contributed by each component.

${ }^{*} P$ value of fixation index after 9999 random permutations.
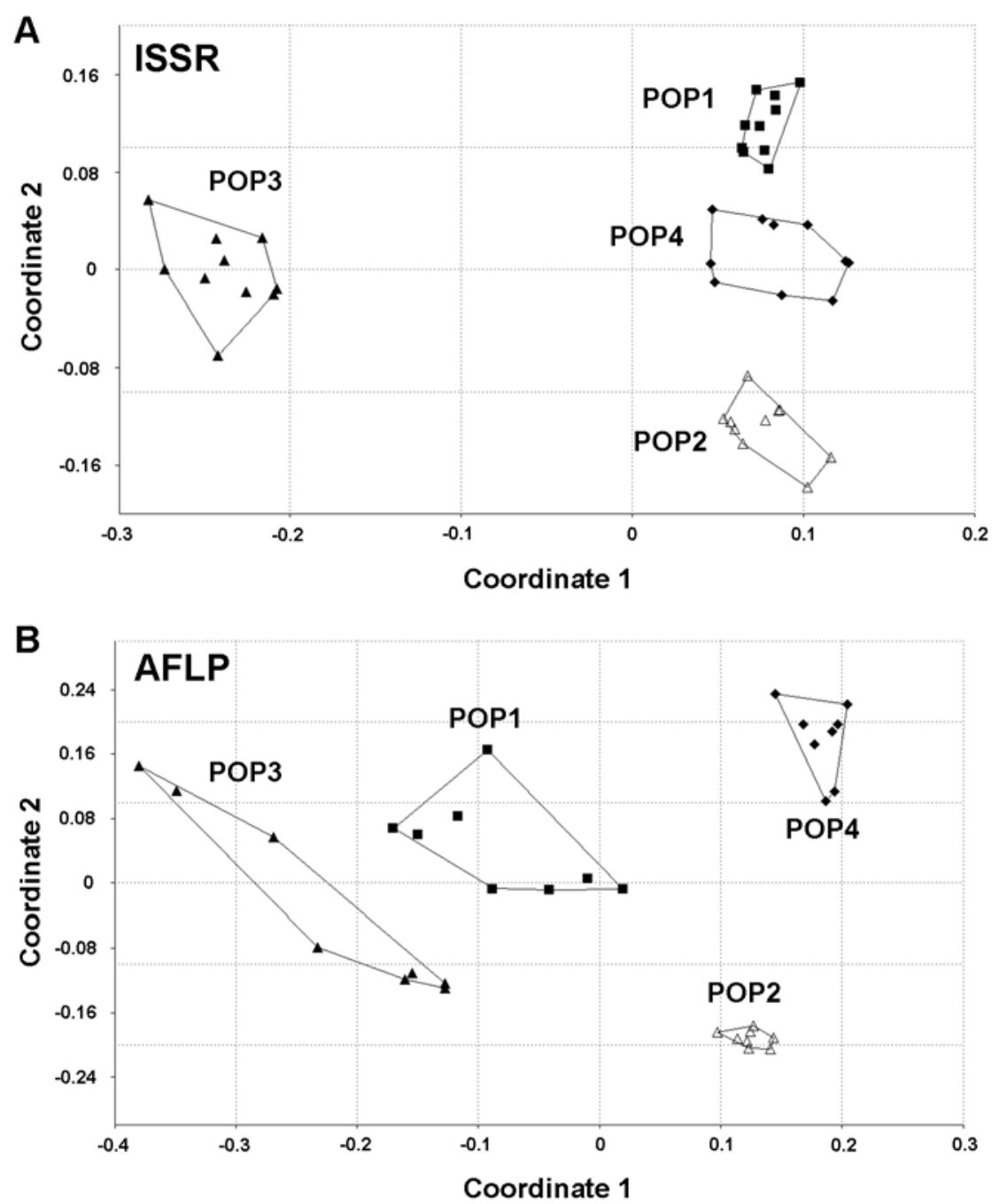

Fig. 2. Principal Coordinates Analysis (PCoA) from four populations of $R$. cabrerensis s.l. based on the correlation matrix of presence/absence of ISSR and AFLP fragments. A) ISSR analysis: the first two coordinates explain $46.71 \%$ of the total variance. B) AFLP analysis: the first two coordinates explain $28.02 \%$ of the total variance. Individuals belonging to the same population are enclosed in convex hull. POP1 $=$ filled squares $(\boldsymbol{\square})$; POP2 $=$ open triangle $(\triangle)$; POP3 $=$ filled triangle $(\boldsymbol{\Delta})$; POP4 $=$ filled diamonds $(\bullet)$. Populations are coded as in Table 1.

atively high level of genetic differentiation among populations. The estimated number of migrants per generation $(\mathrm{Nm})$ from $G_{\mathrm{ST}}$ was 0.541 (ISSR analysis) and 1.332 (AFLP analysis) (Table 4), which suggested a moderate-high rate of gene flow among populations. The Mantel test showed that there was significant correlation between geographical distance and pairwise genetic distance based on ISSR data $(r=0.7269, P=$ 

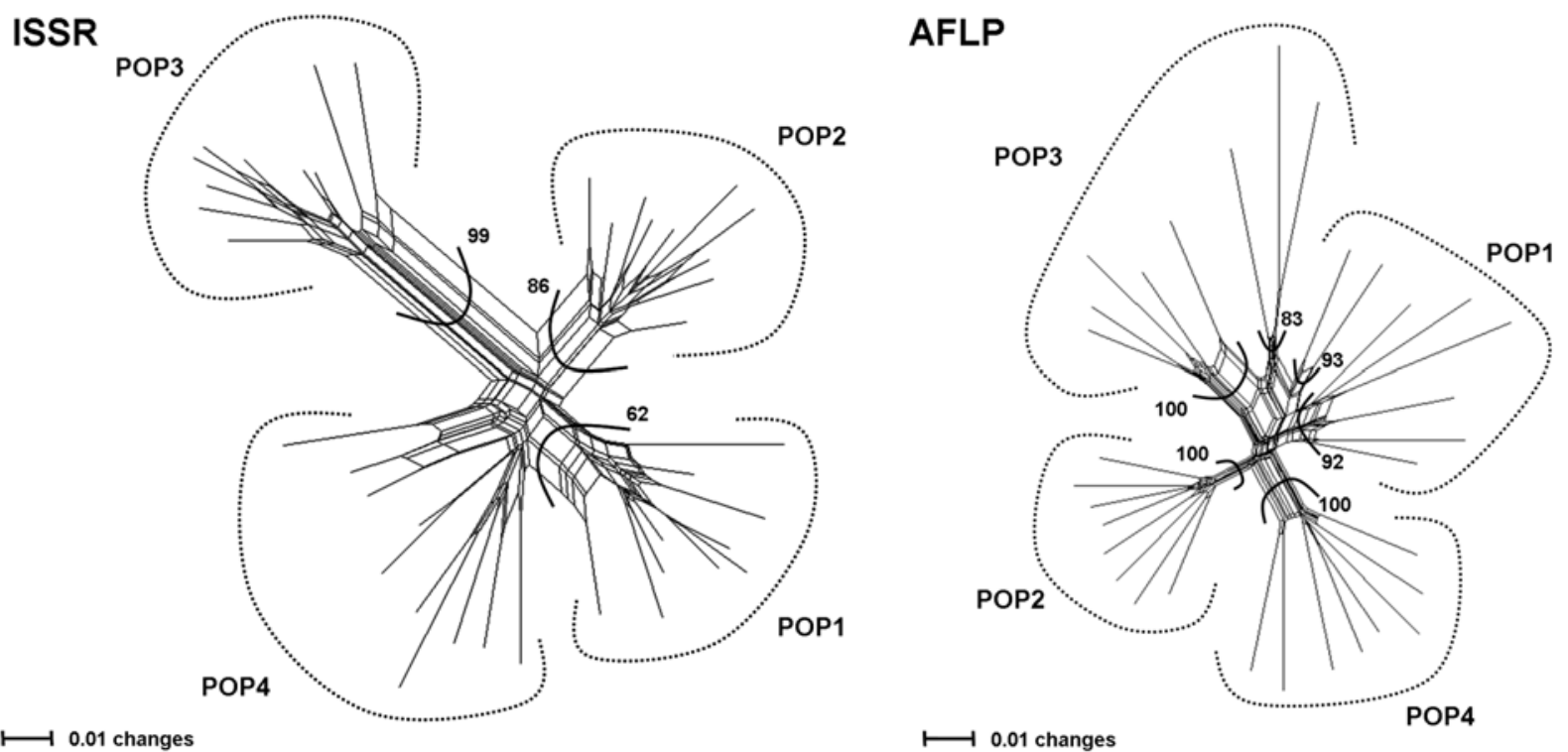

Fig. 3. NeighborNets derived from ISSR and AFLP data of R. cabrerensis s.l. Bootstrap support values over 50\% (analysis of 5,000 replicates) are shown on the relevant branches. The least squares fit indexes for the split network were 93.75 and $97.38 \%$ for ISSR and AFLP respectively. Population numbers correspond to the populations as mapped in Fig. 1 and listed in Table 1.

\section{Mean likelihood values}

A

\begin{tabular}{ccc}
\hline & \multicolumn{2}{c}{ ISSR Structure } \\
\cline { 2 - 3 } $\mathrm{K}$ & $\ln \operatorname{Pr}(\mathrm{X} / \mathrm{K})$ & $\operatorname{Var}[\operatorname{LnP}(\mathrm{X} / \mathrm{K})]$ \\
\hline 1 & -2597.94 & 383.53 \\
2 & -2256.26 & 512.78 \\
3 & -2146.13 & 601.40 \\
$\mathbf{4}$ & $-\mathbf{2 0 7 0 . 1 4}$ & $\mathbf{6 9 4 . 9 2}$ \\
5 & -2074.06 & 699.41 \\
6 & -2075.32 & 698.70 \\
7 & -2079.68 & 703.21 \\
8 & -2093.90 & 704.24 \\
9 & -2086.46 & 710.07 \\
10 & -2100.47 & 710.03 \\
\hline
\end{tabular}

$A^{\prime}$

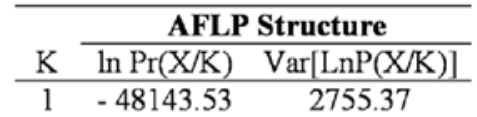

AFLP
$2 \quad \mathbf{- 4 7 7 9 3 . 0 6} \quad \mathbf{3 6 6 0 . 9 2}$

$3 \quad-47801.51 \quad 3678.40$

$\begin{array}{lll}4 & -47802.00 & 3677.30\end{array}$

$\begin{array}{lll}5 & -47807.08 & 3686.14\end{array}$

$\begin{array}{lll}6 & -47796.93 & 3659.47\end{array}$

$\begin{array}{lll}7 & -47797.65 & 3658.57\end{array}$

$\begin{array}{llll}8 & -47799.71 & 3661.14\end{array}$

$9 \quad-47801.15 \quad 3663.43$

$\begin{array}{lll}10 & -47811.46 & 3683.93\end{array}$

\section{Evanno method}

B

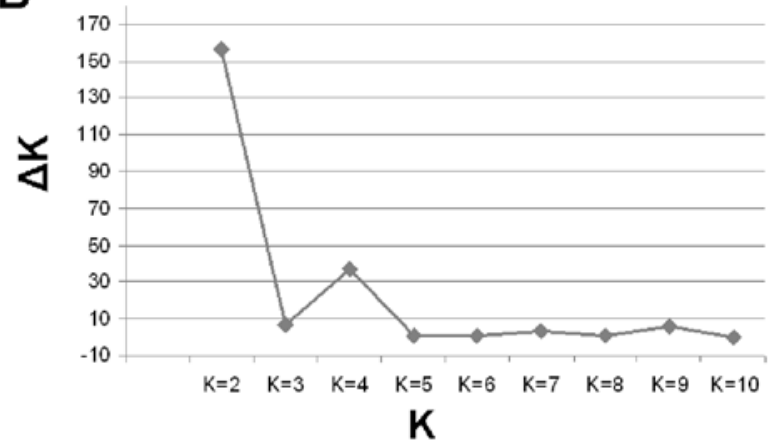

B'

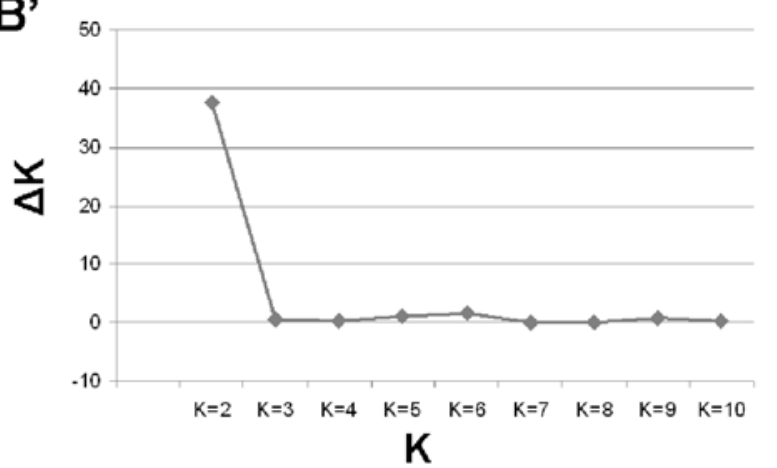

Fig. 4. Bayesian clustering approach in R. cabrerensis s.l. based on ISSR and AFLP data. A-A') Mean of ten independent runs for each value of $K$ ranging from 1 to 10 . In bold: most probable number of clusters (highest $\ln \operatorname{Pr}(X / K)$; Var: variance of the likelihood). B-B') Plot of $\Delta K$ for each $K$ value calculated as described in Evanno et al. (2005) where $K$ is the number of clusters.

0.0001). However, AFLP data did not show such a pattern of isolation by distance $(r=0.0441, P=0.2989)$.

Genetic clustering

Principal Coordinates Analysis based on ISSR and
AFLP data revealed four main groups (Fig. 2). In accordance with the PCoA analysis, the NeighborNet (Fig. 3) illustrates four major splits corresponding to the number of geographical regions. Additionally, Bayesian clustering of individuals from the four 

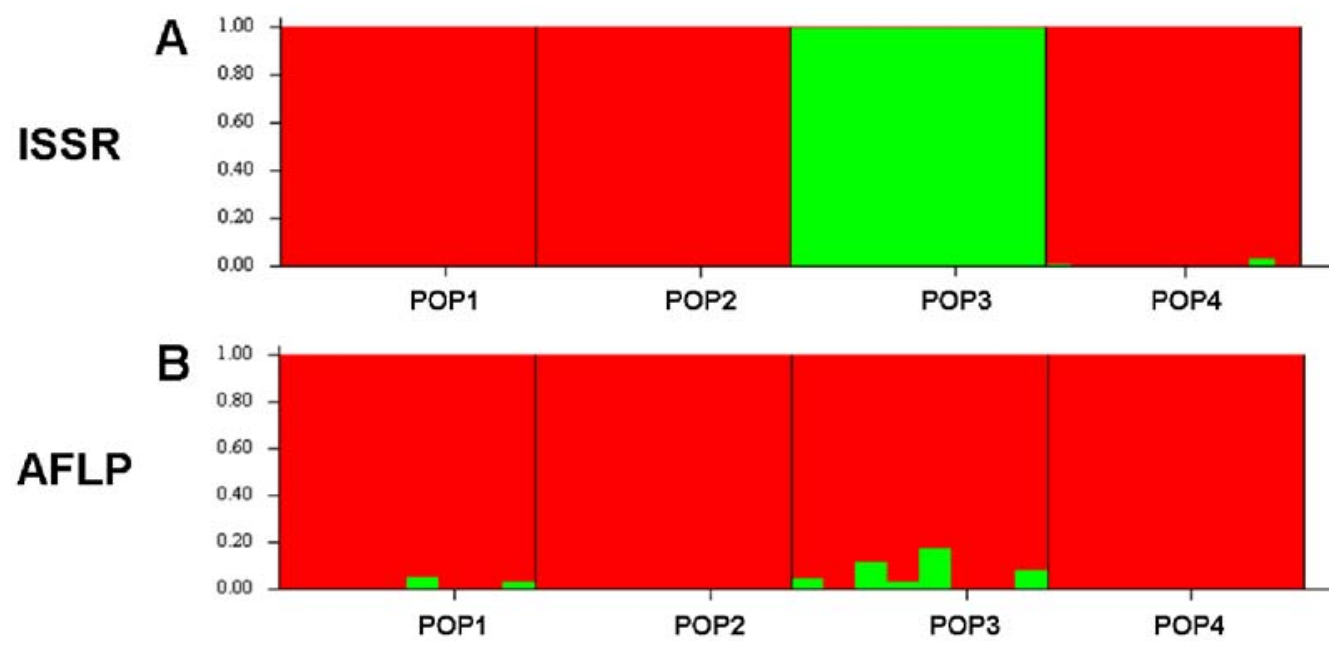

Fig. 5. Bar plot of population assignment proportions according to Evanno's statistic $(\Delta K)$. Bayesian approach in $R$. cabrerensis s.l. based on ISSR (A) and AFLP (B) data. Vertical lines corresponding to the populations studied. Each individual is represented by a column filled with different colours.

populations was run nine times for every value of $K$ (from 1 to 10). At each round of the process, the consistency of the $\ln \operatorname{Pr}(X / K)$ values among the different runs with the same $K$, compared to the variability observed among runs with different $K \mathrm{~s}$, indicated that runs used were sufficiently long (data not shown). The results of the different rounds of the process are summarized in Fig. 4(A-A'). In the case of ISSR analysis, the estimator of posterior probabilities of $K$ indicated that the most likely $K$ was $4(-2070.14)$, so four groups were inferred, corresponding to the populations studied. However, applying the method of Evanno et al. (2005) to the Structure results provided evidence for two genetic clusters (Fig. 4B and Fig. 5A). Therefore, $\Delta K$ is highest for $K=2$ because there is a hierarchical structure in the data set. In such situations, the uppermost hierarchical level of population structure is detected. In the case of AFLP analysis, both method (mean likelihood values and Evanno) for 9 independent runs was $K=2$ (Fig. 4B-B'). The two genetically different groups (Fig. 5B) corresponded closely to the groups recognized by the PCoA (Fig. 2). Moreover, both ISSR and AFLP analysis showed a clear barrier separating POP3 from the other populations when Monmonier's maximum difference was used as implemented in the BARRIER 2.2 software in a comparison of $F_{\mathrm{ST}}$ values and geographic distances.

\section{Discussion}

\section{Genetic diversity}

The documentation of genetic diversity and differentiation observed between populations using molecular markers provides initial guidance for conservation and can contribute to the setting of conservation priorities among populations (e.g. Neel \& Ellstrand 2003). Estimates of genetic diversity derived by dominant molecular markers (i.e. ISSR and AFLP) are usually similar and directly comparable (Nybom 2004). These dominant markers have been used to study a large number of endemic and/or endangered species from different plant families in order to develop conservation strategies, as well as in testing genetic relationships between species (e.g. González-Pérez et al. 2009). Our results from AFLP and ISSR show similar overall trends for genetic diversity and population structure. Nevertheless, the genetic diversity indices from ISSR are higher than those from AFLP due to ISSR tending to produce somewhat high estimates of within-population variation (Nybom 2004).

According to the characteristics of $R$. cabrerensis s.l. populations (i.e. fragmented, endemic and rare) we had predicted that there should be low genetic diversity, but generally speaking, it seems that the total genetic diversity based on ISSR and AFLP markers is similar to, or slightly higher, than most of those described by different authors in other species. In fact, Nei's gene diversity estimates in other AFLP studies ranged from 0.07-0.26 (Gaudeul et al. 2000; Rottenberg \& Parker 2003; Barnaud \& Houliston 2010; Chen et al. 2010; Gong et al. 2010) and in the case of ISSR analysis ranged from 0.10-0.28 (Qiu et al. 2004; Xiao et al. 2004; Wu et al. 2004; Shao et al. 2009; Jeong et al. 2010). In addition, determining levels of diversity within species and populations, as well as ascertaining how species diversity is apportioned within and among populations, is useful in formulating strategies for conserving diversity within taxa (Hamrick et al. 1991). The present study indicates that the majority of genetic diversity of $R$. cabrerensis s.l. populations is contained within populations, as indicated by the $G_{\mathrm{ST}}$ value of 0.316 and 0.158 in the ISSR and AFLP analysis respectively. This result agrees with those observed in a compilation of studies using RAPD markers (Nybom $2004)$ for other long-lived perennials $\left(G_{\mathrm{ST}}=0.27\right)$, endemic species $\left(G_{\mathrm{ST}}=0.18\right)$, and plants whose seed dispersal mechanism is based on gravity $\left(G_{\mathrm{ST}}=0.32\right)$. Moreover, literature values obtained with allozymes in different combinations of life history traits (life form, seed dispersal mechanism and geographical range) by 
Hamrick \& Godt (1996) are also consistent with our results.

Gene flow among populations is one of the factors involved in maintaining genetic diversity within a species and depends on dispersal rates (Slatkin 1994). Species with a limited potential for gene flow show more differentiation among populations than do species with high levels of gene flow (Hamrick et al. 1991). A migration rate of 0.5 was considered sufficient by Ellstrand \& Elam (1993) to overcome the diversifying effects of random drift. For $R$. cabrerensis s.l., the effective gene flow per generation ( $N m$ of 0.541 and 1.332 in the ISSR and AFLP analysis respectively), was slightly higher than one successful migrant per generation, indicating considerable gene flow among populations that has effectively homogenized populations to some degree (Slatkin 1987), and that genetic drift has not yet had a major influence on these $R$. cabrerensis s.l. populations. Indeed, this homogenization of the population is reflected in the Bayesian analyses (Figs. 4 and 5). The relatively high $N m$ value for the studied populations is probably attributable to the smaller adjacent range of sampling, and also to the similar ecogeographical environment with frequent wind.

It is worth noting the high genetic diversity among subspecies, also reflected in the presence of private and discriminating fragments. This variability is considered of great importance for possible adaptation to environmental changes and, consequently, for the long-term survival of a species (Sosa et al. 2002). In addition, both taxa grow in a relatively specialised alpine habitat of coarse rock-fields, areas which seem to be especially sensitive to global environmental change.

\section{Conservation implications}

Successful management and preservation of populations of rare, threatened or endangered species depends on knowledge of the levels of genetic diversity of the target species (Frankham et al. 2004). In situ conservation is usually the preferred strategy for most wild plant species, because its dynamic nature enables ongoing evolution. Another criterion for conservation is maintaining geographical connectivity to ensure gene flow and preserve genetic diversity. Based on genetic diversity and differentiation, proposed efficient and practical conservation strategies for the endangered species $R a$ nunculus cabrerensis are as follows.

First, since there is relatively high differentiation among populations, the loss of populations at certain locations may not only cause immediate loss in genetic diversity, but it will also cause considerable damage in terms of long-term genetic consequences due to the reduced number of populations and the small population size. Thus, the priority must be to protect all the existing populations in situ and prevent anthropogenic destruction, allowing them to propagate and increase in size through natural regeneration. In addition to this, due to the close proximity between populations and the moderate-high rate of gene flow among them, the conservation of all these patches is required to maintain high genetic variability. This is of great importance from a conservation point of view, because a network of small, interconnected demes could maintain more genetic variability than a single, large, random-mating population (Fischer \& Matthies 1998), and hence it could be less susceptible to genetic drift although more vulnerable to demographic stochasticity (Gliddon \& Goudet 1994).

Second, although it does not appear that ex situ conservation is required at present, it might be necessary in the future, so we wish to highlight that samples should be collected from as many populations as possible, especially the eastern population (POP3), characterized by its relatively high genetic diversity. Because of the long life-cycle of $R$. cabrerensis, the seed and germplasm collections in botanical gardens or other institutions could be of practical value for the conservation of its genetic diversity. At this point, we would also like to note that a special strategy in the short and long term should be followed for the only known population of $R$. cabrerensis subsp. muniellensis, as has already been suggested for this highly endangered taxon (Cires 2011).

Finally, periodic visits to the natural locations of $R$. cabrerensis s.l. are also recommended in order to register demographic patterns. As there is no historic data on the size and dynamics of these patches of plants, we suggest that ecological data such as number of plants, pollination biology and seed dispersal should be gathered, as well as searching for new locations of this species. The information obtained in this study provides the basis of a clear framework for developing a conservation programme for the endangered species $R$. cabrerensis.

\section{Acknowledgements}

This research was funded by the Spanish Ministerio de Educación y Ciencia (CGL2006-11743). E. Cires is supported by a predoctoral grant from the University of Oviedo (UNOV06-BECDOC-2).

\section{References}

Bañares A., Blanca G., Güemes J., Moreno J.C. \& Ortíz S. (eds). 2004. Atlas y libro rojo de la flora vascular amenazada de Espańa. Dirección General de la Conservación de la Naturaleza, Madrid.

Barnaud A. \& Houliston G.J. 2010. Population genetics of the threatened tree daisy Olearia gardneri (Asteraceae), conservation of a critically endangered species. Conserv. Genet. 11: 1515-1522.

Bellusci F., Palermo A.M., Pellegrino G. \& Musacchio A. 2008. Genetic diversity and spatial structure in the rare, endemic orophyte Campanula pseudostenocodon Lac. (Apennines, Italy), as inferred from nuclear and chloroplast variation. Plant Biosys. 142: 24-29.

Bueno Sánchez A., Fernández Casado M.A. \& Fernández Prieto J.A. 1992. A new subspecies of Ranunculus parnassiifolius L. (Ranunculaceae) from the Cantabrian Mountains, Spain. Bot. J. Linean Soc. 109: 359-367.

Buza L., Young A. \& Thrall P. 2000. Genetic erosion, inbreeding and reduced fitness in fragmented populations of the endanged tetraploid pea Swainsonia recta. Biol. Cons. 93: 177-186. 
Chen Y.-Y., Liao L., Wei L. \& Zuo-Zhou L. 2010. Genetic diversity and population structure of the endangered alpine quillwort Isoetes hypsophila Hand.-Mazz. revealed by AFLP markers. Pl. Syst. Evol. 290: 127-139.

Ci X.-Q., Chen J.-Q., Li Q.-M. \& Li J. 2008. AFLP and ISSR analysis reveals high genetic variation and inter-population differentiation in fragmented populations of the endangered Litsea szemaois (Lauraceae) from Southwest China. Pl. Syst. Evol. 273: 237-246.

Cires E. 2011. Unravelling the polyploid complex Ranunculus parnassiifolius L. (Ranunculaceae): A combined morphologic and molecular-genetic approach. PhD dissertation, Universidad de Oviedo, $212 \mathrm{pp}$.

Cires E. \& Fernández Prieto J.A. 2012. The Iberian endemic species Ranunculus cabrerensis Rothm.: an intricate history in the Ranunculus parnassiifolius L. polyploid complex. Pl. Syst. Evol. 298: 121-138.

Cires E., Samain M.-S., Goetghebeur P. \& Fernández Prieto J.A. 2011. Genetic structure in peripheral Western European populations of the endangered species Cochlearia pyrenaica (Brassicaceae). Pl. Syst. Evol. 297: 75-85.

Cuesta C., Ordás R., Rodríguez A. \& Fernández B. 2010. PCR$\underline{\text { based molecular markers for assessment of somaclonal vari- }}$ ation in Pinus pinea clones micropropagated in vitro. Biol. Plantarum 54(3): 435-442.

Doyle J.J. \& Doyle J.L. 1987. A rapid DNA isolation procedure for small quantities of fresh leaf tissue. Phytochem. Bull. 19: $11-15$.

Ellstrand N.C. \& Elam D.R. 1993. Population genetic consequences of small population size: implications for plant conservation. Annu. Rev. Ecol. Syst. 24: 217-243.

Evanno G., Regnaut S. \& Goudet J. 2005. Detecting the number of clusters of individuals using the software STRUCTURE: a simulation study. Mol. Ecol. 14: 2611-2620.

Falush D., Stephens M. \& Pritchard J.K. 2007. Inference of population structure using multilocus genotype data: dominant markers and null alleles. Mol. Ecol. Notes 7: $\overline{574-578 .}$

Fernández Prieto J.A., Díaz González T.E. \& Nava Fernández H.S. 2007. La protección de la flora vascular del Principado de Asturias. Naturalia Cantabricae 3: 37-56.

Fischer M. \& Matthies D. 1998. RAPD variation in relation to population size and plant fitness in the rare Gentianella germanica (Gentianaceae). Am. J. Bot. 85: 811-819.

Frankham R., Ballou J.D. \& Briscoe D.A. 2004. Introduction to conservation genetics. Cambridge University Press, Cambridge.

Gaudeul M., Taberlet P. \& Till-Bottraud I. 2000. Genetic diversity in an endangered plant, Eryngium alpinum L. (Apiaceae), inferred from amplified fragment length polymorphism markers. Mol. Ecol. 9: 1625-1637.

Gliddon C. \& Goudet J. 1994. The genetic structure of metapopulations and conservation biology, pp. 107-114. In: Loeschke V., Tomiuk J. \& Jain S.K. (eds), Conservation genetics. Birkhäuser, Basel.

Gong W., Gu L. \& Zhang D. 2010. Low genetic diversity and high genetic divergence caused by inbreeding and geographical isolation in the populations of endangered species Loropetalum subcordatum (Hamamelidaceae) endemic to China. Conserv. Genet. 11(6): 2281-2288.

González-Pérez M.A., Sosa P.A. \& Batista F.J. 2009. Genetic variation and conservation of the endangered endemic Anagyris latifolia Brouss. ex Willd. (Leguminosae) from the Canary Islands. Pl. Syst. Evol. 279: 59-68.

Hammer Ø., Harper D.A.T. \& Ryan P.D. 2001. PAST: paleontological statistics software package for education and data analysis. Palaeontol. Electronica 4: 1-9.

Hamrick J.L. \& Godt M.J.W. 1996. Effects of life history traits on genetic diversity in plant species. Phil. Trans. R. Soc. Lond. B 351: 1291-1298.

Hamrick J.L., Godt M.J.W., Murawshi D.A. \& Loveless M.D. 1991. Correlations between species traits and allozyme diversity: implications for conservation biology, pp. 75-86. In: Falk D.A. \& Holsinger K.E. (eds), Genetics and conservation of rare plants. Oxford University Press, New York.
Höglund J. 2009. Evolutionary conservation genetics. Oxford University Press, Oxford, 189 pp.

Huson D.H. \& Bryant D. 2006. Application of phylogenetic networks in evolutionary studies. Mol. Biol. Evol. 23: 254-267.

Jeong J.H., Kim E.H., Guo W., Yoo K.O., Jo D.G. \& Kim Z.S. 2010. Genetic diversity and structure of the endangered species Megaleranthis saniculifolia in Korea as revealed by allozyme and ISSR markers. Pl. Syst. Evol. 289: 67-76.

Jones C.J., Edwards K.J., Castaglione S., Winfield M.O., Sale F., Van de Wiel C., Bredemeijer G., Buiatti M., Maestri E., Malcevshi A., Marmiroli N., Aert R., Volckaert G., Rueda J., Linacero R., Vazquez A. \& Karp A. 1997. Reproducibility testing of RAPD, AFLP and SSR markers in plants by a network of European laboratories. Mol. Breed. 3: 381-390.

Li J. \& Jin Z. 2007. Genetic variation and differentiation in Torreya jackii Chun, an endangered plant endemic to China. Plant Sci. 172: 1048-1053.

Llamas F., Acedo C., Lence C., Alonso R., Molina A. \& Castro V. 2007. Flora cantábrica de interés en Castilla y León. Naturalia Cantabricae 3: 57-78.

Manni F., Guérard E. \& Heyer E. 2004. Geographic patterns of genetic, morphologic, linguistic variation: how barriers can be detected by "Monmonier's algorithm". Human Biol. 76: 173-190.

Moreno J.C. (coord.) 2008. Lista roja 2008 de la flora vascular espańola. Dirección General de Medio Natural y Política Forestal (Ministerio de Medio Ambiente, y Medio Rural y Marino, y Sociedad Espańola de Biología de la Conservación de Plantas), Madrid, 86 pp.

Neel M.C. \& Ellstrand N.C. 2003. Conservation of genetic diversity in the endangered plant Erigonum ovalifolium var. vineum (Polygonaceae). Conserv. Genet. 4: 337-352.

Nei M. 1972. Genetic distance between populations. Amer. Nat. 106: $283-392$.

Nei M. 1977. F-statistics and analysis of gene diversity in subdivided populations. Ann. Hum. Genet. 41: 225-233.

Nybom H. 2004. Comparison of different nuclear DNA markers for estimating intraspecific genetic diversity in plants. Mol. Ecol. 13: 1143-1155.

Peakall R. \& Smouse P.E. 2006. GENALEX 6: genetic analysis in Excel. Population genetic software for teaching and research. Mol. Ecol. Notes 6: 288-295.

Pritchard J.K., Stephens M. \& Donnelly P. 2000. Inference of population structure using multilocus genotype data. Genetics 155: 945-959.

Qiu Y.-Y., Hong D.-H. \& Fu C.-X. 2004. Genetic variation in the endangered and endemic species Changium smyrnioides (Apiaceae). Biochem. Sys. Ecol. 32: 583-596.

Rottenberg A. \& Parker J. 2003. Conservation of the critically endangered Rumex rothschildianus as implied from AFLP diversity. Biol. Cons. 114: 299-303.

Shao J.W., Chen W.L., Peng Y.Q., Zhu G.P. \& Zhang X.P. 2009. Genetic diversity within and among populations of the endangered and endemic species Primula merrilliana in China. Biochem. Sys. Ecol. 37: 699-706.

Slatkin M. 1994. Gene flow and population structure, pp. 3-17. In: Real L.A. (ed.), Ecological genetics. Princeton University Press, New Jersey.

Slatkin M. 1987. Gene flow and the geographic structure of natural populations. Science 236: 778-792.

Slatkin M. \& Barton N.H. 1989. A comparison of three indirect methods for estimating average levels of gene flow. Evolution 43: $1349-1368$.

Smith T.B. \& Wayne R.K. 1996. Molecular genetic approaches in conservation. Oxford University Press, Oxford, 483 pp.

Sosa P., Batista F.J., González M.A. \& Bouza N. 2002. La conservación genética de las especies vegetales amenazadas, pp. 133-160. In: Bañares Baudet Á. (coord.), Biología de la conservación de plantas amenazadas. Técnicas para el diagnóstico del estado de conservación. Organismo Autónomo de Parques Nacionales. Ministerio de Medio Ambiente, Madrid.

Tomimatsu H. \& Ohara M. 2003. Genetic diversity and local population structure of fragmentation of Trillium camschatcense. Biol. Cons. 109: 249-258. 
Travis S.E., Maschinski J. \& Keim P. 1996. An analysis of genetic variation in Astragalus cremnophylax var. cremnophylax, a critically endangered plant, using AFLP markers. Mol. Ecol. 5: $735-745$.

Vekemans X. 2002. AFLP-SURV. Laboratoire de Génétique et Ecologie Végétale, Université libre de Bruxelles, Bruxelles, Belgium.

Vos P., Hogers R., Bleeker M., Reijand M., van de Lee T., Hornes M., Frijers A., Pot J., Peleman J., Kuiper M. \& Zabeau M. 1995. AFLP: a new technique for DNA fingerprinting. Nucleic Acids Res. 23: 4407-4414.

VV AA. 2000. Lista roja de la flora vascular espańola (valoración según categorías UICN). Conservación Vegetal 6(extra): 139.
Wu C.-J., Cheng Z.-Q., Huang X.-Q., Yin S.-H., Cao K.-M. \& Sun C.-R. 2004. Genetic diversity among and within populations of Oryza granulata from Yunnan of China revealed by RAPD and ISSR markers: implications for conservation of the endangered species. Plant Sci. 167: 35-42.

Xiao L.Q., Ge X.J., Gong X., Hao G. \& Zheng S.X. 2004. ISSR variation in the endemic and endangered plant Cycas guizhouensis (Cycadaceae). Ann. Bot. 94: 133-138.

Zhivotovsky L.A. 1999. Estimating population structure in diploids with multilocus dominant DNA markers. Mol. Ecol. 8: $907-913$.

Zietkiewicz E., Rafalski A. \& Labuda D. 1994. Genome fingerprinting by simple sequence repeat (SSR)-anchored polymerase chain reaction amplification. Genomics 20: 176-183.

Received December 5, 2011

Accepted August 20, 2012 